\title{
Killer Yeasts - Cause of Stuck Fermentations in a Wine Cellar
}

\author{
H.J.J. van Vuuren ${ }^{1}$ and Brenda D. Wingfield ${ }^{2}$
}

${ }^{1}$ Associate Professor and ${ }^{2}$ Researcher

Department of Microbiology, Institute for Biotechnology, University of Stellenbosch, Stellenbosch 7600, South Africa.

Submitted for publication: July 1986

Accepted for publication: September 1986

Keywords: Killer yeasts, stuck wine fermentations, flocculation.

\begin{abstract}
Sluggish fermentations in five fermenters in a wine cellar were investigated. Methylene blue-stains of yeast suspensions revealed that approximately $90 \%$ of the total yeast population in each of the fermenters were dead. The viable cells in each fermenter were killer yeasts. Polyacrylamide gel electrophoresis of total soluble cell proteins showed that the same killer yeast occurred in each of the five fermenters. The effect of killer yeast on viability and fermentation activity of the wine yeast was studied in an enriched grape juice medium at $20^{\circ} \mathrm{C}$ and $30^{\circ} \mathrm{C}$. Death rate of the wine yeast was considerably higher in the presence of the killer yeast and fermentations were retarded at both temperatures. The killer yeast induced flocculation of the non-flocculent wine yeast.
\end{abstract}

Protracted or stuck fermentations cause serious problems in the wine industry. The phenomenon leads to longer fermentation times and high residual fermentable sugars in dry wines. These factors and the inferior quality of the final product result in financial losses to wineries.

Some sluggish fermentations appear to be associated with musts deficient in oxygen and nutrients, low fermentation temperatures, compounds toxic to yeast, yeast strains, and even variation in climate, soil type and cultivation, soil moisture, fertilizer practices and grape varieties (Agenbach, 1977; Bell, Ough \& Kliewer, 1979; Geneix, Lafon-Lafourcade \& RibéauGayon, 1983; Tromp, 1981; Ingledew \& Kunkee, $1985)$. There is no agreement on how to avoid stuck fermentations (Blackburn, 1984). Since production of wine is brought about by yeast-mediated fermentation of grape must, protracted or stuck fermentations can only be ascribed to yeast metabolism slowing down and eventually stopping.

Killer yeasts are known to occur in wineries (Naumov et al., 1973; Shimizu et al., 1985). These yeasts secrete a proteinaceous killer toxin lethal to susceptible or sensitive strains of the same species. Neutral strains exist that do not produce a toxin and are not sensitive to the killer factor. Killer strains are immune to their own toxin (Bevan \& Makower, 1963). However, socalled K/S killer strains are sensitive to toxins produced by certain other killer strains (Woods, Ross \& Hendry, 1975).

Killer yeasts possess two major types of double stranded RNA (dsRNA), the L and M genomes, that are separately encapsidated in virus-like particles. The M-genome codes for the toxin and immunity to this polypeptide (Mitchell \& Bevan, 1983). Based on the properties of the killer toxin, killer yeasts are classified into at least 11 groups (K1-K11), three of which (K1, K2 and K3) are specific to Saccharomyces cerevisiae. The K1 killers were first described by Bevan \& Makower (1963). The $\mathrm{K} 1$ toxin is sensitive to high temperatures, proteases and the optimum $\mathrm{pH}$ for the produc-

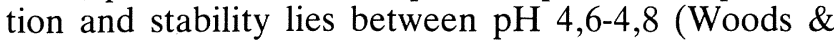
Bevan, 1968). K1 killers are therefore not important in fermenting grape must as their toxin is inactive at low $\mathrm{pH}$. However, the $\mathrm{K} 2$ killer toxin is stable at $\mathrm{pH} 2,8-4,8$ (Shimizu et al., 1985).

K2 killers have been isolated from wine (Naumov \& Naumova, 1973; Naumov et al., 1973), beer (Maule \& Thomas, 1973; Rogers \& Bevan, 1978) and laboratory yeast strains (Young \& Yagiu, 1978). Not much is known about the K3 killer toxin. Killer types K4-K11 occur among other genera and species viz; Candida, Cryptococcus, Debaryomyces, Hansenula, Kluyveromyces, Pichia, Saccharomyces (non cerevisiae), Ustilago and Torulopsis (Young \& Yagiu, 1978). Therefore the K2 killer yeasts and possibly the K3 killers pose a threat to the wine industry since their toxins are lethal to sensitive wine yeasts in grape must fermentations.

In this study we report on the occurrence and properties of K2 killer yeasts isolated from five stuck fermentations in a wine cellar. The effect of the killers on wine yeast grape juice fermentations is discussed. Our findings indicate that these killer yeasts were responsible for the stuck fermentations.

\section{EXPERIMENTAL PROCEDURES}

\section{Viability of Yeast in Stuck Fermentations:}

The methylene blue-staining technique was used (Anon, 1971).

\section{Yeast strains:}

A Sacch. cerevisiae strain from Geisenheim, used to inoculate two of the stuck wine fermentations, was obtained from Stellenbosch Farmers' Winery (Pty) Ltd. Killer yeasts were isolated from five commercial wine fermentations (T205, T206, T214, T234 and T243) which ceased to ferment before sugars had been depleted. Samples taken from tanks where stuck fermentations occurred were streaked onto yeast extract malt extract (YM) agar plates and incubated at $26^{\circ} \mathrm{C}$ for 48 hours. Single colonies were purified by successive streaking on YM agar. Stock cultures were made on YM agar plates and kept at $4^{\circ} \mathrm{C}$.

\section{Seeded agar phenotype test:}

Low-pH agar medium was prepared by dissolving $6 \mathrm{~g}$ Bacto yeast extract, $12 \mathrm{~g}$, Bacto peptone, $12 \mathrm{~g}$ dextrose 
and $12 \mathrm{~g}$ Bacto agar in $533 \mathrm{ml}$ distilled $\mathrm{H}_{2} \mathrm{O}$. After sterilization $67 \mathrm{ml}$ phosphate citrate buffer $(\mathrm{pH} \mathrm{4,5)}$ and methylene blue $\left(20 \mathrm{mg}\right.$ in $5 \mathrm{ml}$ of $\left.\mathrm{H}_{2} \mathrm{O}\right)$ were added aseptically. One millilitre of Geisenheim yeast actively growing in YM medium was spread onto previously dried low-pH agar plates. Yeast strains isolated from stuck fermentations were cultured in YM broth at $26^{\circ} \mathrm{C}$. After 18 hours they were spotted on agar plates previously spread with Geisenheim yeast. The plates were incubated at $26^{\circ} \mathrm{C}$ for 48 hours.

\section{Characterization of yeast strains by poly-acrylamide gel electrophoresis of total soluble cell proteins:}

Culture conditions: Individual yeast strains were inoculated in $30 \mathrm{ml} \mathrm{YM}$ broth in $250 \mathrm{ml}$ Erlenmyer flasks and incubated at $30^{\circ} \mathrm{C}$ for 10 hours on a rotary shaker. Each liquid culture was transferred to $120 \mathrm{ml}$ of YM broth in a $250 \mathrm{ml}$ Erlenmyer flask and incubated for a further 9 hours while shaking. The $150 \mathrm{ml}$ culture was finally inoculated into $850 \mathrm{ml}$ YM broth in a $1 l$ Erlenmyer flask and incubated (stationary) for 15 hours.

Preparation of cell-free extracts: Yeast cells were harvested and washed once by centrifugation in $0,01 \mathrm{M}$ phosphate buffer $\mathrm{pH} \mathrm{7,0} \mathrm{and} \mathrm{twice} \mathrm{in} \mathrm{3,2} \mathrm{mM} \mathrm{Tris-HCI}$ buffer $\mathrm{pH} 7,0$. All Tris-HCI buffers were made up in bidistilled water. Five millilitres of $6,4 \mathrm{mM}$ Tris-HCI buffer $\mathrm{pH} 8,4$ containing $0,001 \%$ deoxyribonuclease (Sigma Chemical Company, St. Louis, U.S.A.) and $5 \mathrm{ml}$ of $0,5 \mathrm{~mm}$ diameter glass beads were added to approximately $4 \mathrm{~g}$ (wet weight) yeast cells. Cells were disrupted in an Edmund Bühler cell mill (Edmund Bühler, Tübingen, West Germany) for 10 minutes. Intact cells and debris were removed by centrifugation $\left(4^{\circ} \mathrm{C}\right.$, $15000 \mathrm{x} \mathrm{g}, 15$ minutes) in a Beckman J2-21 centrifuge. Approximately $4 \mathrm{ml}$ of turbid supernatant was centrifuged for 1 hour at $4^{\circ} \mathrm{C}(80000 \mathrm{x} \mathrm{g})$ in a Beckman L8$55 \mathrm{M}$ ultracentrifuge. Two millilitres of this extract was centrifuged for a further 4 hours at $4^{\circ} \mathrm{C}$ and $80000 \mathrm{x} \mathrm{g}$. Protein extracts were stored at $-18^{\circ} \mathrm{C}$. The protein concentration was determined by the Folin-Lowry method (Plummer, 1971) and adjusted to a concentration of $12 \mathrm{mg} / \mathrm{m} l$ with $6,4 \mathrm{mM}$ Tris-HCI buffer $\mathrm{pH} \mathrm{8,4}$. Bovine serum albumin (Nutritional Biochemicals Corporation) was used as the standard.

Polyacrylamide gel electrophoresis: The method described by Kersters \& De Ley (1975) was used with some modifications. Instead of distilled water, a $5 \mathrm{~mm}$ layer of n-butanol was carefully applied on top of the acrylamide gel with an Agla micrometer syringe (Wellcome Reagents Limited, Wellcome Research Laboratories, Beckenham, England).

Electrophoresis was performed in a GE-2/4 Gel Electrophoresis Apparatus (Pharmacia Fine Chemicals, Sweden). The electrode buffer $(0,064 \mathrm{M}$ Tris-HCI, $\mathrm{pH}$ $8,7)$ was circulated from the lower to the upper electrode chamber and kept at $8-9^{\circ} \mathrm{C}$ by water circulating in a.glass coil from an Endocal refrigerated bath (Neslab Instruments Inc., Portsmouth, U.S.A.). Each protein extract was run at least three times.

Photography and normalization of photographs: Methods described by Kersters \& De Ley (1975) were used. However, Ilford, Ilfospeed photographic paper (grade 1,1 m) was used.

\section{Isolation of virus-like particles:}

Virus-like particles (VLPs) were isolated using a modification of the method described by Adler, Wood \& Bozarth (1976). Yeast cells were cultured in $100 \mathrm{ml}$ of modified CM broth ( $4 \%$ glucose, $0,5 \%$ yeast extract and $0,3 \%$ peptone) at $26^{\circ} \mathrm{C}$. After 24 hours the yeast suspension was added to 1 litre of CM broth. After 3 days cells were harvested by centrifugation at $10000 \times \mathrm{g}$ for 20 minutes. To every $4 \mathrm{~g}$ (wet weight) of cells, $5 \mathrm{ml}$ of buffer $(0,03 \mathrm{M}$ sodium phosphate $(\mathrm{pH} \mathrm{7,5)}$ and 0,15 $M$ sodium chloride) and $5 \mathrm{ml}$ of glass beads $(0,5 \mathrm{~mm}$ diameter) were added. The yeast cells were homogenized in an Edmund Bühler homogenizer (Edmund Bühler, Tübingen, West Germany) for 10 minutes. The homogenate was centrifuged at $12000 \mathrm{x}$ g for $30 \mathrm{~min}-$ utes and polyethylene glycol added to the supernatant (final concentration $4 \%$ ). The suspension was allowed to stand on ice for 2 hours and then centrifuged (27000 $\mathrm{x} \mathrm{g}$ ) for 30 minutes. The pellet was resuspended in the same buffer and the VLPs were harvested by highspeed centrifugation through a $5 \mathrm{ml}$ underlayer of cesium chloride $(0,4 \mathrm{~g} / \mathrm{m} l)$ for 2 hours at $4^{\circ} \mathrm{C}(163000 \mathrm{x} \mathrm{g})$. Pellets were resuspended in $0,15 \mathrm{M}$ ammonium acetate $(\mathrm{pH} 7,5)$ or processed further for double-stranded RNA isolation.

\section{Electron microscopic examination of virus-like par- ticles:}

Drops of viral suspension were placed on carbon coated "Collodion flexible" grids, washed with water, negatively stained with $2 \%$ sodium phosphotungstate, and examined in a Hitachi H300 electron microscope.

\section{Isolation of double-stranded RNA:}

Double-stranded RNA (dsRNA) was isolated from the VLPs. The VLP pellet was resuspended in $50 \mathrm{mM}$ Tris-HCI $(\mathrm{pH} 8,0)$ and $10 \mathrm{mM} \mathrm{MgCl}_{2}$ and contaminating nucleic acids were removed by digesting with DNase I (final concentration $200 \mu \mathrm{g} / \mathrm{m} l$ ) and RNase A (final concentration $200 \mu \mathrm{g} / \mathrm{m} l$ ) for 30 minutes at $37^{\circ} \mathrm{C}$. The VLPs were further purified by a second cesium chloride centrifugation and the resulting pellet resuspended in $20 \mathrm{mM}$ Tris-HCI (pH 8,0) $10 \mathrm{mM}$ EDTA and $0,5 \%$ SDS. Proteinase $\mathrm{K}$ was added (final concentration $200 \mu \mathrm{g} / \mathrm{ml}$ ) and allowed to digest for 1 hour at $37^{\circ} \mathrm{C}$. The dsRNA was extracted twice with phenol, once with chloroform:isoamyl alcohol (24:1), the aqueous layer removed and $1 / 10$ volumes of $3 \mathrm{M}$ sodium acetate and 2,5 volumes of ethanol added. The precipitate was pelleted by centrifugation for 30 minutes at $15000 \times \mathrm{g}$, the pellet washed with $70 \%$ ethanol and the dsRNA was dissolved in $10 \mathrm{mM}$ Tris-HCI $(\mathrm{pH} \mathrm{8,0)}$ and $1 \mathrm{mM}$ EDTA for electrophoresis. Electrophoresis of dsRNA in 1\% Agarose gels was done using the method of Bolivar \& Backman (1979) with $0,5 \mu \mathrm{g} / \mathrm{m} l$ ethidium bromide added to the gel and running buffer $(89 \mathrm{mM}$ Tris borate, $89 \mathrm{mM}$ boric acid and $8 \mathrm{mM}$ EDTA).

\section{Effect of killer yeasts on fermentation:}

Culture procedures: The Sacch. cerevisiae strain from Geisenheim and the killer yeast isolated from stuck fermentation T206 were each inoculated into $10 \mathrm{~m} l$ YMbroth in $50 \mathrm{ml}$ Erlenmyer flasks and incubated at $26^{\circ} \mathrm{C}$ for 20 hours on a rotary shaker. Each culture was added to $100 \mathrm{~m} l$ commercial grape juice (Monis) previously diluted with water $(1: 1)$ and enriched with $0,5 \%$ yeast 
extract (Merck), 0,05\% di-ammonium hydrogen-phosphate and $0,0005 \%$ (v/v) Tween 80 (DGM medium). The $250 \mathrm{~m} l$ Erlenmyer flasks were incubated on a rotary shaker at $26^{\circ} \mathrm{C}$ for 24 hours. Each yeast was cultured in duplicate. The cells were harvested by centrifugation (10000 rpm for 15 minutes) under sterile conditions. The Geisenheim yeast was resuspended in $200 \mathrm{~m} l$ sterile DGM broth and the killer yeast (T206) in $30 \mathrm{~m} l \mathrm{DGM}$ broth. Yeast counts were done using the plate count method and YM agar.

Fermentations: Fermentation trials were conducted in two Multigen Fermenters (New Brunswick Scientific, Edison, N.J., U.S.A.) using sterile enriched grape juice broth (DGM broth pH 3,2) as substrate. Both fermenters were inoculated with $70 \mathrm{ml}$ Geisenheim yeast suspension. Subsequently, the one fermenter was inoculated with $7 \mathrm{ml}$ of killer yeast (strain T206) suspension. The killer yeast population in the DGM broth was $2 \times 10^{5}$ cells $/ \mathrm{m} l$ and that of the Geisenheim yeast $1 \times 10^{8}$ cells $/ \mathrm{m} l$. The final volume in both fermenters was $1552 \mathrm{~m} l$. The fermentation temperature was controlled at $20^{\circ} \mathrm{C}$ by an Endocal refrigerated circulating water bath (Neslab Instruments Inc., Portsmouth, U.S.A.). The experiment was repeated at $30^{\circ} \mathrm{C}$. The viability of the yeast suspension was monitored daily by using the methylene blue-staining technique and the specific gravity of the fermenting grape juice was measured.

\section{RESULTS AND DISCUSSION}

Microscopic examination of methylene blue-stained yeast cells in the five stuck commercial fermentations revealed that approximately $90 \%$ of the total yeast population in each of the fermenters were dead. The dead yeast cells were much smaller than the viable cells and their shape was different (Fig. 1). Yeast cells killed by by the killer factor are usually shrunken (Bussey, 1974). Furthermore, results obtained with the seeded agar phenotype test revealed that the Geisenheim wine yeast was sensitive to the killer toxin and that the viable yeast cells in all five stuck fermentations were killer yeasts (Fig. 2).

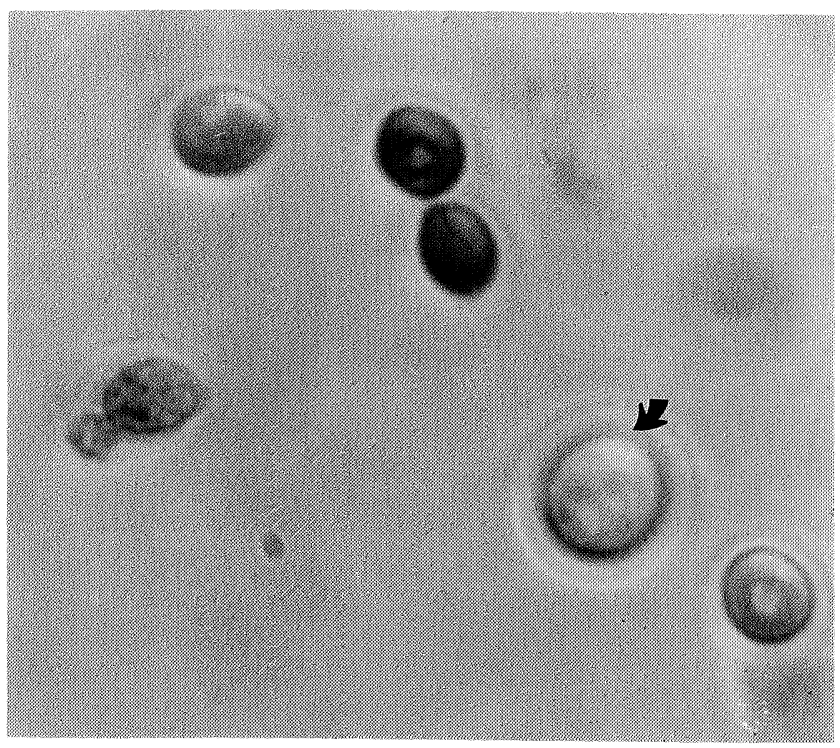

FIG. 1

Photomicrograph of methylene blue-stained wine yeast cells from fermenter T206. The stain is concentrated in dead yeast cells. Viable yeast cells were subsequently shown to be killer yeasts

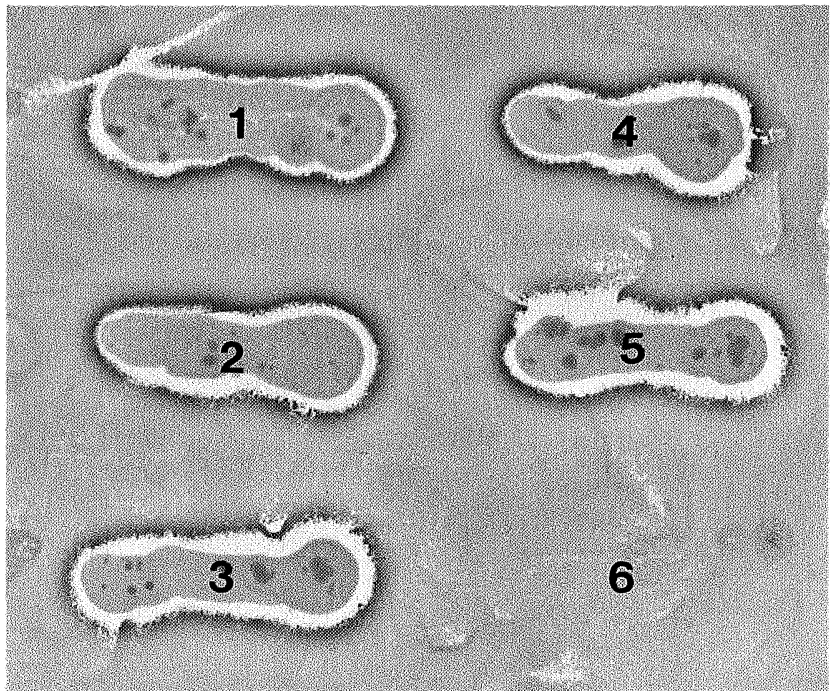

FIG. 2

Samples of killer yeasts isolated from fermenters T205, T206, T214, $\mathrm{T} 234, \mathrm{~T} 243(1-5)$ and a neutral strain (6) inoculated onto a methylene blue-containing agar medium previously spread with Geisenheim yeast. Dark zones indicate dead Geisenheim yeast cells.

Fingerprinting of yeasts by protein electrophoresis is a valuable tool to identify individual strains (van Vuuren \& van der Meer, In Press). The total soluble cell proteins of killer yeasts isolated from stuck fermentations as well as the Geisenheim yeast originally used in two of the tanks are presented in Figure 3. It is clear that the same killer yeast strain occurred in each of the five fermenters. Furthermore, the protein pattern of the killer yeast differs from that of the Geisenheim wine yeast which was used to inoculate two of the fermenters. The other three tanks were originally inoculated with Sacch. cerevisiae (Assmanshausen). However, this yeast strain was not available for investigation.

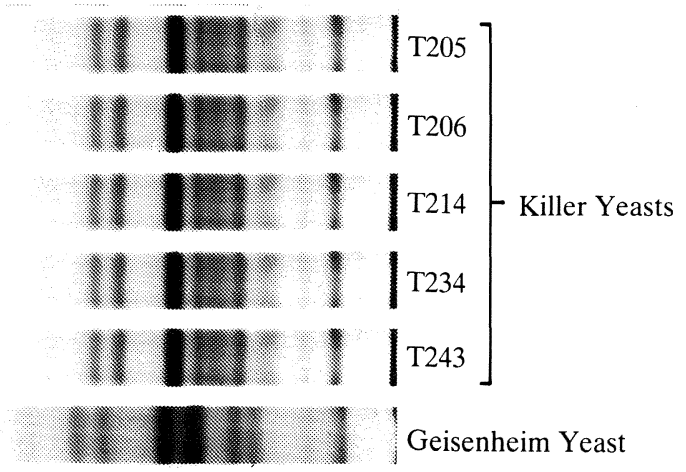

FIG. 3

Normalized gel photographs of total soluble cell proteins of five killer yeasts from different fermenters and the Geisenheim wine yeast.

Figure 4 is a micrograph of the VLPs isolated from killer yeast T206. The VLPs from K1 and K2 killer yeasts contain two major types of dsRNA: L and M dsRNA. Both types of dsRNA were isolated from VLPs obtained from the killer yeasts found in the stuck fermentations (Fig. 5). The Geisenheim yeast did not contain any VLPs. The M dsRNA is known to code for the production of the kill r toxin (Bostian \& Tipper, 1984). However, the activity and stability at low pH va- 


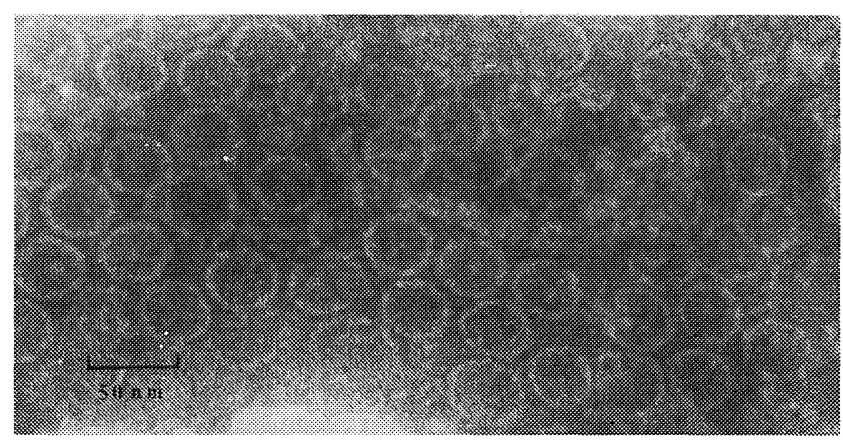

FIG. 4

Electron micrograph of virus-like particles from killer yeast T206.

lues and high temperatures of the $\mathrm{K} 1$ and $\mathrm{K} 2$ toxins differ markedly. Optimum production and stability of the $\mathrm{K} 1$ killer factor lie within the narrow $\mathrm{pH}$ range of 4,64,8 (Woods \& Bevan, 1968). In contrast, the K2 killer factor is stable at $\mathrm{pH} 2,8-4,8$ (Shimizu et al., 1985). These differences imply a different toxin structure which in turn means that the M2 dsRNA that codes for the production of the $\mathrm{K} 2$ toxin is also different. We are currently investigating the dsRNAs isolated from the K2 killer yeast T206.

The effect of the killer yeast on the viability and fermentation activity of the Geisenheim yeast strain at $20^{\circ} \mathrm{C}$ and $30^{\circ} \mathrm{C}$ is presented in Figures 6 and 7 respectively. At both temperatures the killer yeast decreased the viability of the wine yeast and the rate of fermentation. The death rate of the yeast cells in the presence of the killer yeast was significantly higher. For example, in the presence of the killer yeast only $30 \%$ of the total

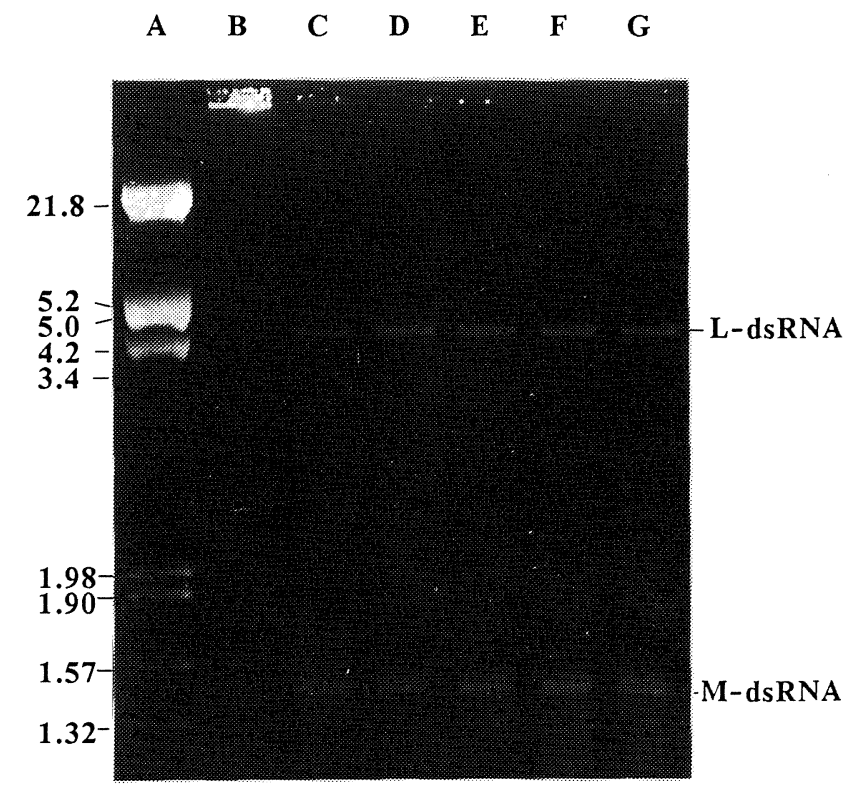

FIG. 5

Agarose gel of dsRNA isolated from killer yeasts (lane A, phage lambda DNA cut with Hind III and Eco RI. Fragment sizes are indicated in kilobases. Lane B, Geisenheim wine yeast; lanes $C-G$, killer yeasts T205, T206, T214, T234 and T243 respectively).

population remained viable after 3 days at $20^{\circ} \mathrm{C}$. However, in the control fermentation, $97 \%$ of the yeast cells remained viable. At $30^{\circ} \mathrm{C}$, mortality of yeast cells both in the presence and absence of the killer yeast was higher than at $20^{\circ} \mathrm{C}$. Viability of the Geisenheim yeast in the presence of killer yeast could not be monitored after

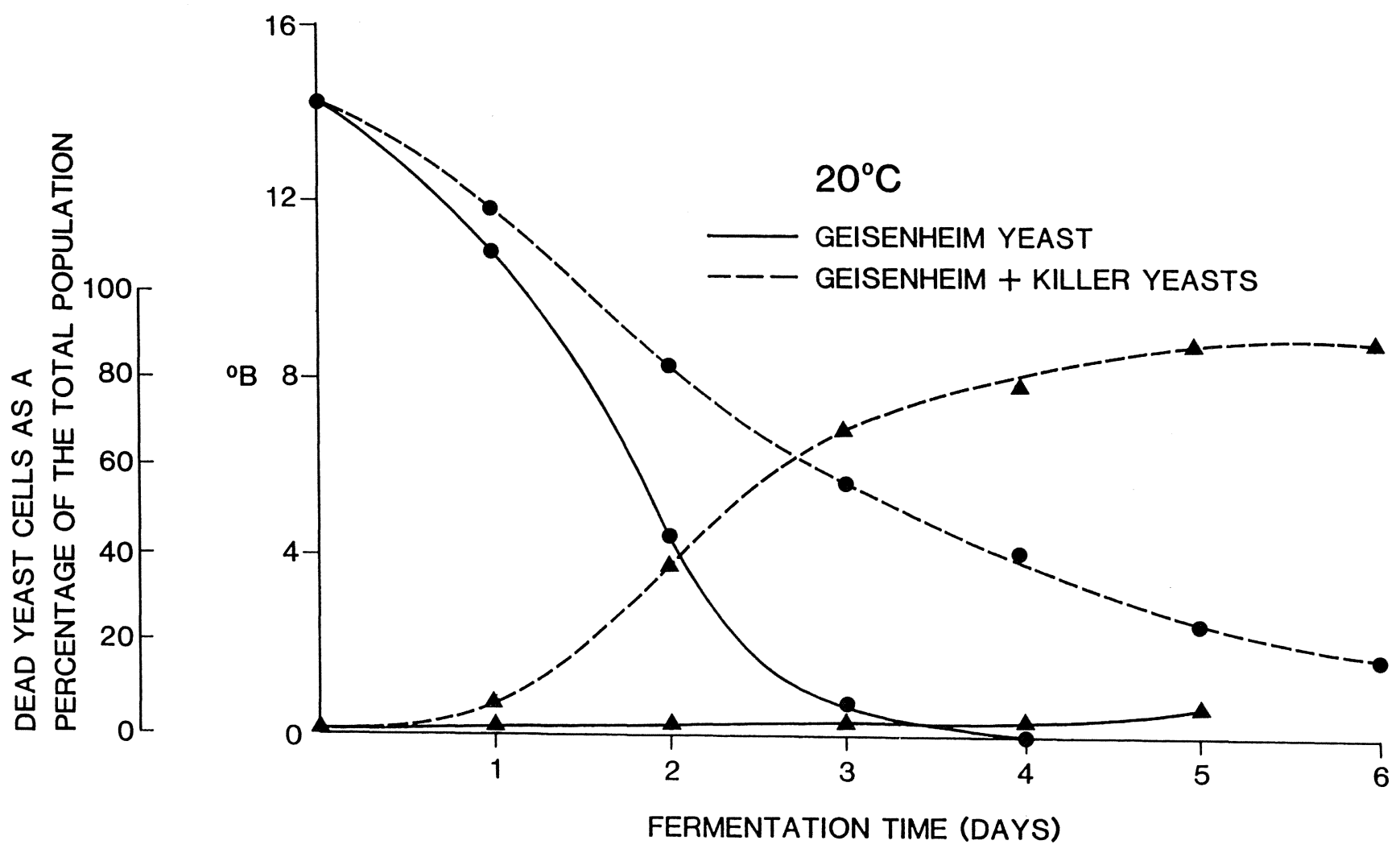

FIG. 6

The effect of killer yeast on the fermentation rate $(\bullet)$ and viability

$(\boldsymbol{\Delta})$ of wine yeast during fermentation at $20^{\circ} \mathrm{C}$. 


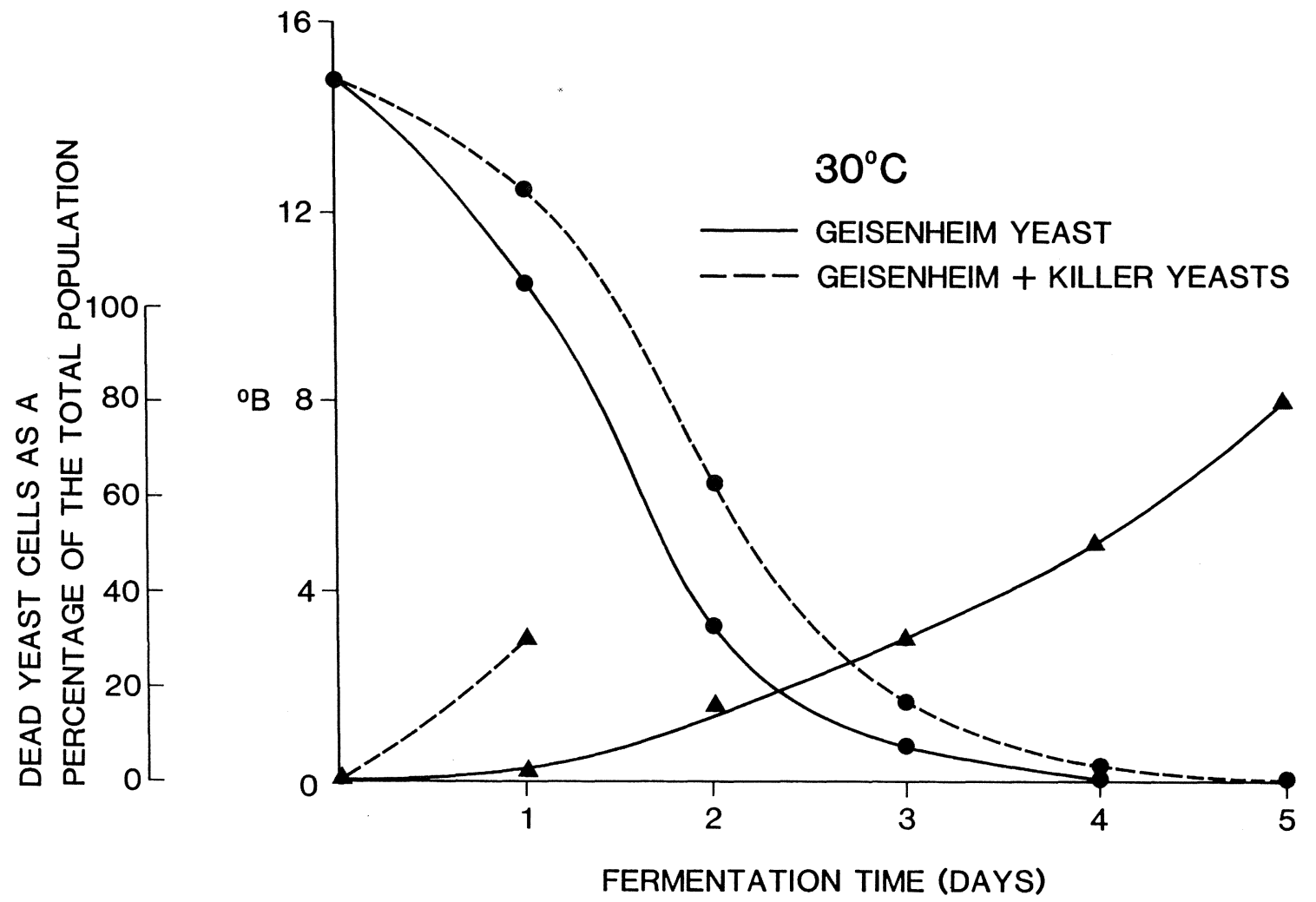

FIG. 7

The effect of killer yeast on the fermentation rate $(\bullet)$ and viability

$(\boldsymbol{\Delta})$ of wine yeast during fermentation at $30^{\circ} \mathrm{C}$.

one day due to extensive flocculation and clump formation.

The control fermentation at $20^{\circ} \mathrm{C}$ was complete after 4 days, whereas fermentation in the presence of the killer yeast was incomplete even after 6 days. Although the rate of fermentation in the presence of the killer yeast was slower at $30^{\circ} \mathrm{C}$, it was completed one day after the control fermentation. The killer yeast probably grew more rapidly at $30^{\circ} \mathrm{C}$ than at $20^{\circ} \mathrm{C}$ and might have completed the fermentation. However, even at $30^{\circ} \mathrm{C}$ the effect of the killer toxin on the viability of the wine yeast and its fermentation activities was obvious.

The killer yeast cell concentration will affect the course of a wine fermentation inoculated with a sensitive yeast strain. Low fermentation temperatures (12$\left.15^{\circ} \mathrm{C}\right)$ and high ethanol concentrations $(>5 \%)$ will inhibit growth of killer yeast cells which may be present at low concentrations, still sufficient to kill the wine yeast, resulting in a stuck fermentation. Higher initial concentrations of killer yeast will lead to death of the wine yeast and a sluggish fermentation that could still be completed by the killer yeast.

Flocculation has been reported in yeasts used in the manufacture of beer but not in wine fermentation. Flocculation refers to the ability of yeast to aggregate spontaneously and form flocs which sediment in the culture during the stationary phase of growth (Stewart \& Russell, 1981). During fermentation the Geisenheim yeast flocculated only in the presence of the killer yeast. Microscopic examination of the grape juice medium revealed that flocculation of both strains occurred and only a few cells remained in suspension.
Even vigorous agitation for 15 minutes did not resuspend the cells. Flocculation was observed when the killer yeast was cultured separately under identical conditions in DGM broth. The adhesion of one cell to another is frequently mediated by salt bridges in which $\mathrm{Ca}^{2+}$ ions play an important role (Taylor \& Orton, 1975). It has been speculated that other molecules such as polypeptides might be involved in bridge formation (Stewart, Russel \& Garrison, 1975). Results from this study indicate that the toxin produced by the killer yeast mediated flocculation of the non-flocculent wine yeast strain. It would be interesting to know how many flocculating yeast strains produce killer toxins.

The use of killer yeasts to eliminate undesirable yeasts in fermenting grape must has been advocated (Hara et al., 1981; Seki, Choi \& Ryu, 1985) and such strains are commercially available. However, the toxin produced by Sacch. cerevisiae is only lethal to sensitive and K/S strains. Neutral and killer strains will therefore not be eliminated. Futhermore, reports on the ability of killer yeasts to kill other yeasts species or genera are conflicting. Bostian \& Tipper (1984) found that killer yeasts secrete toxins which kill sensitive cells of the same species and frequently those of other yeast species and genera. However, according to Mitchell \& Bevan (1983) killer toxin produced by Sacch. cerevisiae is lethal to other strains of the same species. Young \& Yagiu (1978) determined that non-Saccharomyces strains, with the exception of Torulopsis glabrata (NCYC 388), were not killed by Saccharomyces spp. Furthermore, Hara et al. (1981) reported that a hybrid killer wine yeast only killed Saccharomyces yeast in grape must. 
The ability of killer Sacch. cerevisiae wine yeasts to eliminate yeasts of other genera and species thus seems limited. Seki, Choi \& Ryu (1985) suggested the construction of a wine yeast harbouring multiple killer factors. However, cytoplasmic dsRNA is known to occur only in Saccharomyces spp. and Ustilago maydis (Koltin \& Day, 1976) and the genetic construction of such a killer yeast strain seems doubtful.
We believe that the use of killer yeasts to eliminate foreign yeasts in commercial wineries has limited application. In fact, we consider it a dangerous practice as contamination of the wine cellar with killers is inevitable and subsequent use of sensitive strains may result in protracted or stuck fermentations. We suggest that neutral yeast strains be used to inoculate grape must to overcome sluggish fermentations due to killer toxins.

\section{LITERATURE CITED}

ADLER, J., WOOD, H.A. \& BOZARTH, R.F. 1976. Virus-like particles from killer, neutral and sensitive strains of Saccharomyces cerevisiae. J. Virol. 17(1), 472-476.

AGENBACH, W.A. 1977. A study of must nitrogen content in relation to incomplete fermentations, yeast production and fermentation activity. Proc. South African Enol. Vitic. 66-87.

ANON. 1971. Recommended Methods of Analysis. J. Inst. Brew. 77, 181-226.

BEVAN, E.A. \& MAKOWER, M. 1963. The physiological basis of the killer character in yeast. In: Geerts, S.J. (ed.) Genetics Today, XIth Int. Congr. Genet., Vol.1, Pergamon Press, Oxford pp. 202-203.

BELL, A.A., OUGH, C.S. \& KLIEWER, W.M. 1979. Effects on must and wine composition, rates of fermentation, and wine quality of nitrogen fertilization of Vitis vinifera var. Thompson Seedless grape-vines. Am. J. Enol. Vitic. 30, 124-129.

BLACKBURN, D. 1984. Coping with stuck fermentations. Practical Winery 4: 51-58.

BOLIVAR, F. \& BACKMAN, K. 1979. Plasmids of Escherichia coli as cloning vectors. Methods Enzymol. 78, 345-354.

BOSTIAN, D.J. \& TIPPER, K.A. 1984. Double-stranded ribonucleic acid killer systems in yeast. Microbiol. Rev. 48, 125-156.

BUSSEY, H. 1974. Yeast killer factor-induced turbidity changes in cells and sphaeroplasts of a sensitive strain. J. Gen. Microbiol. 82, 171-179.

GENEIX, C., LAFON-LAFOURCADE, S. \& RIBEREAUGAYON, P. 1983. Les causes, la prévention et le traitement des arréts de la Vigne et du Vin. Connaissance de la Vigne et du Vin 17, 205-217.

HARA, S., IIMURA, Y., OYAMA, H., KOZEKI, T., KITANO, K. \& OTSUKA, K. 1981. The breeding of cryophylic killer wine yeasts. Agric. Biol. Chem. 45, 1327-1334.

INGLEDEW, W.M. \& KUNKEE, R.E. 1985. Factors influencing sluggish fermentations of grape juice. Am. J. Enol. Vitic. 36(1) 65-76.

KERSTERS, K. \& DE LEY, J. 1975. Identification and grouping of bacteria by numerical analysis of their electrophoretic protein patterns. J. Gen. Microbiol. 87, 333-342.

KOLTIN, Y. \& DAY, P.R. 1976. Inheritance of killer phenotypes and double-stranded RNA in Ustilago maydis. Proc. Natl. Acad. Sci. U.S.A. 73, 594-598.
MAULE, A.P. \& THOMAS, P.D. 1973. Strains of yeast lethal to brewery yeasts. J. Inst. Brew. 79, 137-141.

MITCHELL, D.J. \& BEVAN, E.A. 1983. ScV "Killer" viruses in yeast. In: Spencer, J.F.T., Spencer, D.M. \& Smith, A.R.W. (eds.) Yeast Genetics. Fundamental and Applied Aspects. Springer Verlag, New York, pp. 371-419.

NAUMOV, G.I. \& NAUMOVA, T.I. 1973. Comparative genetics of yeast XIII. Comparative study of killer strains of Saccharomyces from different collections. Genetika 9, 140-145.

NAUMOV, G.I., TYURINA, C.V., BUR'YAN, N.I. \& NAUMOVA, T.I. 1973. Wine-making, an ecological niche of type K2 killer Saccharomyces. Biol. Nauki 16, 103-107.

PLUMMER, D.T. 1971. An Introduction to practical biochemistry. McGraw-Hill Book Company Ltd., London.

ROGERS, D. \& BEVAN, E.A. 1978. Group classification of killer yeasts based on cross reactions between strains of different species and origin. J. Gen. Microbiol. 105, 199-202.

SEKI, T., CHOI, E. \& RYU, D. 1985. Construction of killer wine yeast strain. Appl. Environ. Microbiol. 49(5), 1211-1215.

SHIMIZU, K., ADACHI, T., KITANO, K., SHIMAZAKI, T., TOTSUKA, A., HARA, S. \& DITTRICH, H.H. 1985. Vormen und eigenschaften von "wilden" kıllerhefen bei der Weinbereitung. Die Wein-Wissenschaft 40, 258-270.

STEWART, G.G. \& RUSSELL, I. 1981. Yeast flocculation. In: Pollock, J.R.A. (ed.) Brewing Science, Vol. 2, Academic Press, London.

STEWART, G.G., RUSSELL, I. \& GARRISON, I.F. 1975. Some considerations of the flocculation characteristics of ale and lager yeast strains. J. Inst. Brew. 81, 248-257.

TAYLOR, N.W. \& ORTON, W.C. 1975. Calcium in flocculance of Saccharomyces cerevisiae. J. Inst. Brew. 81, 53-57.

TROMP, A. 1981. Verslag: Besoek aan Europese giskundiges in verband met slepende gisting. NIWW, Stellenbosch, 1-47.

WOODS, D.R. \& BEVAN, E.A. 1968. Studies on the nature of the killer factor produced by Saccharomyces cerevisiae. J. Gen. Microbiol. 51, 115-126.

WOODS, D.R., ROSS, I.W. \& HENDRY, D.A. 1974. A new killer factor produced by a killer/sensitive yeast strain. J. Gen. Microbiol. 81, 285-289.

YOUNG, T.W. \& YAGIU, M. 1978. A comparison of the killer character in different yeasts and its classification. Antonie van Leeuwenhoek J. Microbiol. Ser. 44, 59-77. 